\title{
POSSIBLE CONSEQUENCES OF INCREASING LIFE EXPECTANCY IN BRAZIL. THE PERSPECTIVE OF A EUROPEAN HISTORICAL DEMOGRAPHER
}

\author{
Arthur E. Imhof*
}

\begin{abstract}
IMHOF, A. E. Possible consequences of increasing life expectancy in Brazil. The perspective of a European historical demographer. Rev. Saúde públ., S. Paulo, 21:447-65, 1987.
\end{abstract}

\begin{abstract}
Those over sixty years of age accounted for $6.6 \%$ of the total population of Brazil in 1985, in the Federal Republic of Germany this proportion was 20.3\% in 1984. As early as 1950 it had been $14.5 \%$. This proportion will not even be reached in Brazil in the year 2000 when persons aged sixty years and older are only projected to make up $8.8 \%$ of the total population. Similarly, in $1982 / 84$ life expectancy at birth in the Federal Republic was 70.8 years for men and 77.5 for women; in Brazil the figures for $1980 / 85$ were, by contrast, "only" 61.0 and 66.0 . Against this background it is easy to understand why the discussion concerning an ageing society with its many related medical, economic, individual and social problems has been so slow in coming into its own in Brazil. As important as a more intensive consideration of these aspects may be in Brazil at present, they are, nevertheless, only one side of the story. For a European historical demographer with a long-term perspective of three of four hundred years, the other side of the story is just as important. The life expectancy which is almost ten years lower in Brazil is not a result of the fact that no one in Brazil lives to old age. In 1981 people sixty-five years and older accounted for $34.4 \%$ of all deaths! At the same time infants accounted for only $22.1 \%$ of total mortality. They are responsible, along with the "premature" deaths among youths and adults, for the low, "average" life expectancy figure. In Europe, by contrast, these "premature" deaths no longer play much of a role. In 1982/84 more than half of the women $(52.8 \%)$ in the Federal Republic of Germany lived to see their eightieth birthdays and almost half of the men $(47.3 \%)$ lived to see their seventy-fifth. Our biological existence is guaranteed to an extent today that would have been unthinkable a few generations ago. Then, the classic troika of "plague, hunger and war" threatened our forefathers all the time and everywhere. The radical transition from the formerly uncertain to a present-day certain lifetime, which is the result of the repression of "plague, hunger and war", led to unexpected consequences for our living together. Our forefathers were forced to live in closely knit Gemeinschaften in the interest of physical survival and to subordinate their egoistic goals to a common value, but now these pressures have, for the most part, fallen away. Correspondingly, this much more certain EGO has taken center stage. An ever greater number of us chooses to live life as single beings: the number of marriages is lower every year; the number of divorces is on the increase; in Berlin (West) more than half (sic! $52.3 \%$ ) of all households are already composed on only one person. For the last dozen years the annual number of births in the Federal Republic has been insufficient to ensure population replacement. Not a population explosion but rather the opposite, a population implosion, is our problem. Human beings do not appear to be "social animals", as was axiomatically assumed for so long. They were only forced to behave as such for as long as "plague, hunger and war" forced them to do so. When these life endangering conditions no longer exist and life becomes certain even without their being integrated into a Gemeinschaft then humans suddenly show themselves more and more to be independent single beings. It is not the percentage of the population that is over sixty or sixty-five that is decisive in this context but rather how certain adults perceive their biological lives to be, since they are the ones who organize their lives, who build communities or who are ever more often willing only to enter into means-to-an-end personal unions without lasting or close ties and mutual responsibilities. There are many signs which seem to point to a development in this direction in Brazil as well. More and more adults in Brazil are caught up in the deep-seated transition from an uncertain to a certain lifetime. A third of them die after having reached their sixty-fifth birthday. It therefore seems to me to be high time that one began to give more consideration to the other side of the story in Brazil as well. And who is more suited intensively to consider the long-term perspectives than those engaged in the public health sector in whose competence, after all, such aspects, as "life certainty", "life expectancy" and "age at death" belong?
\end{abstract}

UNITERMS: Demographic transition. Life expectancy. Demographic aging. Brazil/ Germany.

* Department of History, Division of Social History and Historical Demography, Freie Universität Berlin, Habelschwerdter Allee 45, D-1000 Berlin/West 33, Federal Republic of Germany. 


\section{INTRODUCTION}

During a first guest professorship for postgraduate studies in historical demography at the "Universidade Federal do Paraná" (UFPR) in "Curitiba" Brazil and at the "Pontificia Universidade Católica do Rio Grande do Sul" (PUCRS) in "Porto Alegre", Brazil, in 1984 I concentrated on the topic of "Mortality Problems in Brazil and Germany: Past-presentfuture. Learning from each other?" (Imhof ${ }^{19}$ ). During a second such professorship at the same universities in 1986, with new groups of post-graduate students, discussion centered on the topic "Possible consequences of increased life expectancy in Brazil - from the perspecive of a European historical demographer". It could not, of course, be my task in this context to teach Brazilians what they already know better and are able to judge more appropriately than a European coming from abroad (Mundigo ${ }^{30}, 1986$, Fundação $\mathrm{SEADE}^{35}, 1982$ ).

By the same token it is not the intention of this paper to discuss e.g. the economic implications of an aging Brazilian society, nor the resulting necessity of more homes for the aged or more geriatric stations for long-term chronically ill patients. Even though the literature on this topic is not as extensive as in Europe, where we have known these problems for a longer period of time, there is a discussion in progress in Brazil, debates are conducted in daily newspapers, conferences and congresses are held, training courses in geriatrics and gerontology are arranged and scientific studies are published (Boemer ${ }^{3}, 1986$, Born ${ }^{4}$, 1986, Folha de São Paulo ${ }^{18}$, 1986, Gaiarsa ${ }^{14}$, 1986, Gazeta do Povo ${ }^{1,26}, 1986$, Haddad ${ }^{17}, 1986$, LBA $^{12,13}, 1986$ and Leite*, 1986, Mabilde ${ }^{23}$, 1985, Macedo ${ }^{24}, 1983$, Magalhães ${ }^{25}$, 1982, Netto ${ }^{30,31}, 1985$, Netto e col.**, 1983, Prefeitura Municipal de Curitiba ${ }^{32}$, 1986, Queiroz ${ }^{33,34}$, 1986, Salgado ${ }^{36,37}, 1982$. These few references should be enough to prove that Brazilians have obviously not been waiting for us to come and make them aware of the topic of an ageing society and the multitude of problems related to it.

I would much prefer to concentrate on that which I was repeatedly asked, not only by historical demographers but also when speak- ing to gerontologists, sociologists, psychologists, politicians, physicians and others employed in the public health system. They all wanted a European historian to outline some of the longterm perspectives in relation to an increasing life-expectancy on the basis of his European experience, on the one hand, and to try to interpret the current tendencies and developments in Brazil against this background, on the other.

Even though I will try to perform this delicate task in the following, it is, of course, up to every Brazilian to accept my considerations, or to modify or to reject them. The proffered term "tendencies" helps me to overlook some of my own reservations: Reservations with regard to the sources, por example, in the face of the well-known fact that vital statistics are underregistered and the consequently reduced reliability of the "hard facts", on which I, nevertheless, have to base my arguments (Laurenti and col. ${ }^{21}$, 1985: 50-56, 70-73; Mello Jorge ${ }^{27}$, 1983).

Comparing current "tendencies" in Brazil with historical "tendencies" in Europe saves us from the misleading assumption that we are dealing with "parallels" here, with automatisms, with accurately predictable or even calculable developments that are only taking place in Brazil with a time delay of a few decades, but which principally will proceed, or even have to proceed according to the European pattern. A certain probability exists in this context. But it does not have to develop in this direction and certainly not with calculable regularity. Brazil is not Europe and the Brazilians of "Norte, Nordeste, Sudeste, Sul" or "Centro-Oeste" are not the Europeans of Central Europe which populate the horizon of my experience. In short: it is not my main intention to teach historically derived dogma, much less to discuss decimal points, but rather to go beyond the decimal points and to provide food for thought.

\section{The Facts in Brazil}

According to figures from the Brazilian Statistical Bureau (Fundação IBGE ${ }^{10}$ ), infant mortality in $1975 / 80$ was 78.77 per one thousand live births, the life expectancy at birth was 59.54 years for men and 64.25 for women (Figure 1, top). In the Federal Re-

\footnotetext{
* "A Previdência Social e a Aposentadoria no Brasil", manuscript prepared by C. B. Leite, based on the Round-Table held in the "Curso de Formação em Gerontologia Social" ministered by the International Center of Social Gerontology, Rio de Janeiro, July, $7^{\text {th }}$ to $18^{\text {th }}, 1986$.

** Report presented by A. J. Netto and colaborators, on the present situation of the program for the elderly in 1983.
} 


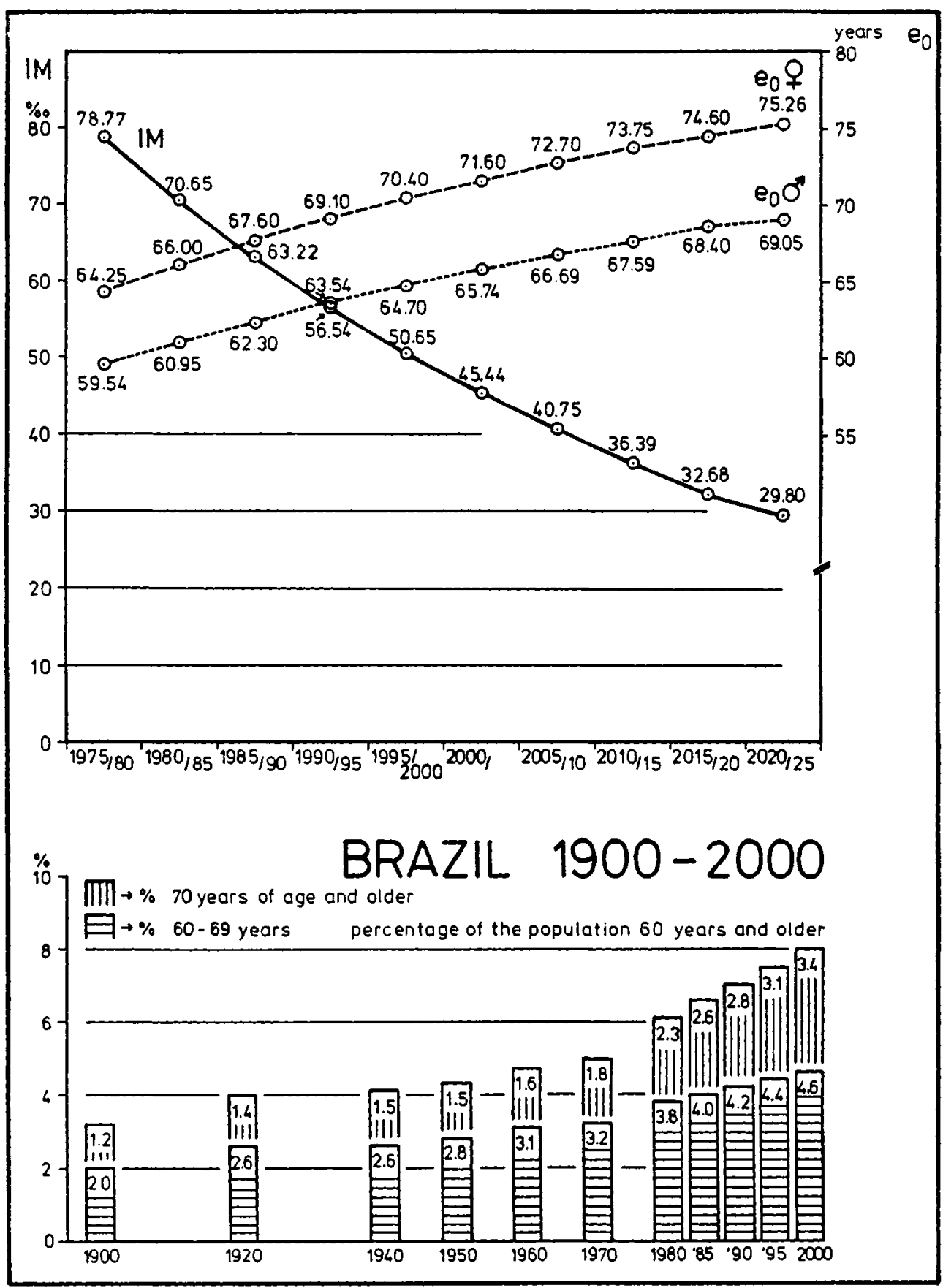

Fig. 1: Brazilian projections for infant mortality, life expectancy, and the percentage of elderly in the population.

Top: The projected development of infant mortality and life expectancy at birth according to sex 1975/80-2020/25.

Bottom: Percentage of the total Brazilian population between sixty and sixty-nine years of age and seventy years of age and older at selected periods between 1900 and 2000 .

Source: Fundação IBGE10, 1986, 60-61, 127. 
public of Germany the infant mortality rate in 1980 was 12.7 and the life expectancy $1982 / 84$ was 70.84 and 77.47 years for men and women respectively (Statistisches Bundesamt $\left.{ }^{40}, 1986: 70,76\right)$. Brazil will still not have caught with to us in the five year period $2020 / 25$ if the figure for infant mortality there is 29.80 per thousand and life expectancy 69.05 and 75.26 years. These are not $m y$ projections and, therefore, not my idea of what I, a foreigner, might consider desirous. On the contrary, they are the goals projected by an official Brazilian bureau and published in the Anuário Estatístico do Brasil 1985 (Fundação $\mathrm{IBGE}^{10}$, 1986: 127). Apparently this development is considered desirous and attainable in the country itself. I simply take them into consideration in the following.

Against this background it is easier to understand why, in Brazil, one so often hears that the infant mortality is much "too high" and the life expectancy is much "too low". That too many life years are lost through diseases that could have been avoided. If we compare recent statistics from both countries with each other, those for Brazil from the year 1982 and those for the Federal Republic of Germany for 1985, the picture that presents itself is highly differentiated. In Brazil 448 people died of diphtheria (032, ICD-9), in the Federal Republic 0. For whooping cough (033) the ratio was 391 to 5 . For tetanus (037) 713 to 6 , for measles (055) 1670 to 5 , for malaria (084) 578 to 22 , and for symptoms, signs and ill-defined conditions of the digestive system (009) a surprising 32,049 to 185 (Ministério da Saúde ${ }^{28}$, 1985: 326-327; Statistisches Bundesamt 1986 1 : 5-9). Even the plague (020) has not been fully eliminated in Brazil. In 1982151 cases were reported none of which, however, ended in death (Fundação IBGE ${ }^{10}$, 1986: 199).

If, in addition, the relatively small proportion of elderly people in Brazil is considered (Figure 1, bottom), then it becomes quite clear why Brazilians consider infant mortality "too high", life expectancy "too low" and "unnecessarily forfeited life years" still seem more important than the problems of an ageing population at the other end of the spectrum. Indeed, Brazilians between the ages of sixty and sixty-nine accounted for only $4.0 \%$ of the population, those seventy years and older for only $2.6 \%$, altogether those aged sixty and older made up only $6.6 \%$ of the population (IBGE ${ }^{10} 1986,61$ ). In the Federal Republic, on the other hand, this group repre- sented $20.3 \%$ of the population in 1984. As early as 1950 the figure in the Federal Republic was as high as $14.5 \%$ (Statistisches Bundesamt ${ }^{40}$, 1986: 62). This figure will not even be attained in Brazil in the year 2000 when the proportion is projected to be $8.0 \%$.

A superficial consideration of all these data can easily lead one to the conclusion that the "aged" and their problems do not carry any real weight in Brazil and merely represent a negligible fringe group at the upper end of the population pyramid. At the bases of this pyramid there is, at present, much to be done and one must, therefore, continue to concentrate primarily on the fastest possible reduction in infant and child mortality as well as the avoidable mortality of people at prime ages.

I do not want to deny for a minute that all these aspects are really still very important in Brazil, in any case more important than they are in Europe. If one makes low infant mortality and high life expectancy in Europe, or anywhere else in the First World, a criterion - as is done in Brazil and in other countries in the Second, Third and Fourth Worlds and as was expressed in the goals set by the Brazilian Statistical Bureau it can, however, easily lead those countries into a dilemma. They want to "catch up" as fast as possible and to at least come close to the "better" figures found in the First World. It seems to me that such a comparative approach is inclined to mask or to excessively repress other important facts.

On the basis of his scientific knowledge the European historical demographer is inclined to cast a critical eye on another development which is just as clearly expressed in the Brazilian figures, if one is willing to recognize it. For this purpose I will repeat a simple experiment that I made with my postgraduate students in Curitiba in order to give them something to think about. In Table 1 the burial lists from a German and a Brazilian city of comparable size from a randomly chosen day in 1986 appear side by side. The German city is Munich (1985: 1,266,100 inhabitants; Statistisches Bundesamt ${ }^{40}, 1986$ : 59), the Brazilian city is Curitiba (1984: 1,227,322 inhabitants; "Departamento Estadual de Estatística"s, 1986: 53).

Although the number of cases for Munich and Curitiba, with 24 and 18 deaths respectively, are relatively small, the life expectancy calculated on the basis of these samples corresponds closely to the current life expectancy 
TABLE 1

First name and age of mortality cases in Munich and Curitiba according to the burial lists from the daily press for a week day in 1986.

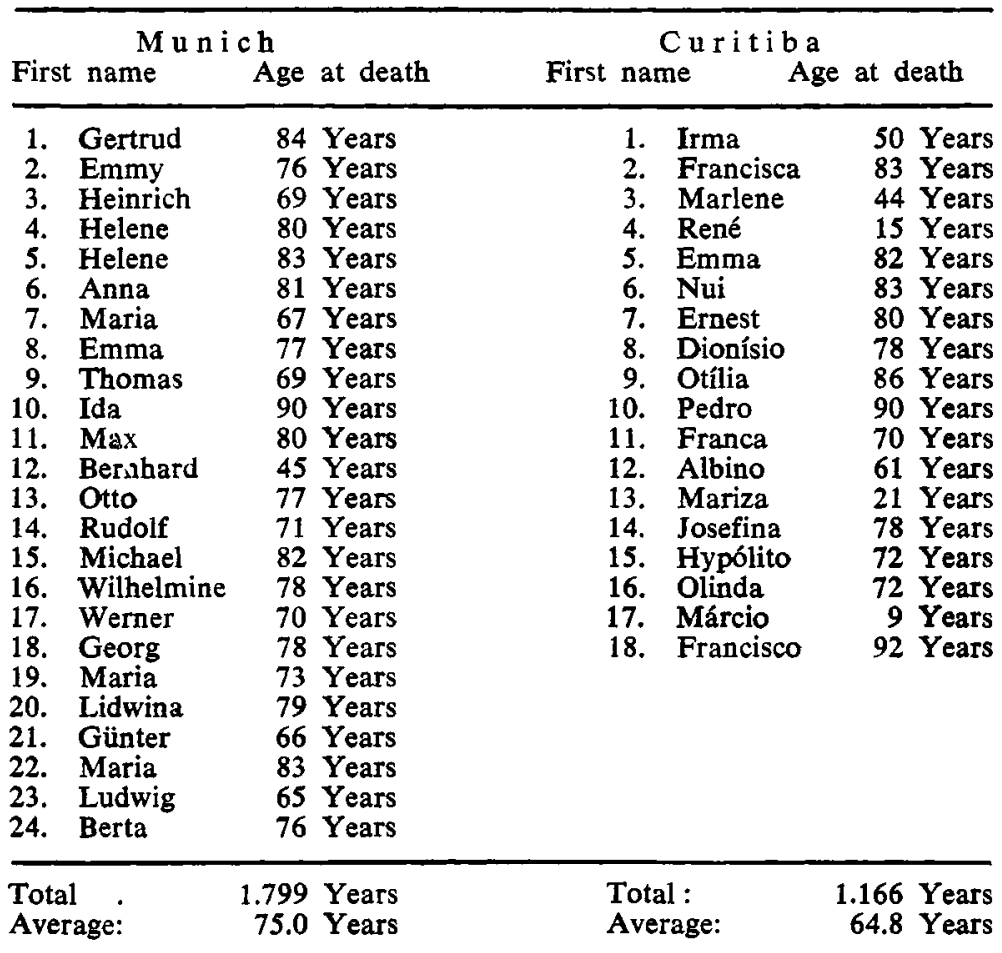

Sources: "Bekanntmachung der Friedhofsverwaltung München über die Bestattungen" (Announcement of burials by the cemitary administration in Munich) from Tuesday, the 20, May 1986; Süddeutsche Zeitung Nr. 113, 20-05-1986, p. 17. "Falecimentos" (List of deaths), Curitiba, Gazeta do Povol, 26-09-1986, p. 2.

in both countries (in 1982/84 men in the Federal Republic could count on 70.8 and women 77.5 years, of life, in Brazil the figures for $1980 / 86$ were 61.0 and 66.0 for men and women respectively). That means we currently have about seventy-five years to live in Central Europe; and the Brazilians about sixty-five. This roughly ten year shorter life expectancy is not, however, a result of the fact that no one in Brazil ever lives to an old or even very old age. Pedro in Curitiba lived to be ninety just as Ida in Munich did; Francisco even lived to be ninety-two exceeding all of the cases reported for Munich. To the same extent, cases of people dying in their eighties are neither seldom in the one nor the other city. Yet what one also finds in Brazil - and this accounts for the greatest difference from Europe - are the massive number of deaths of children, adolescents and young adults (Márcio: nine years old; René: fifteen years old; Mariza: twenty-one years old), not to mention the burials of infants and small children which are obviously not reported in Curitiba. They are the major factor in sinking the "average age at death" and, therefore, the "average life expectancy" in Brazil.

One must avoid being mislead by the population pyramid with its relatively small proportion of aged and the low average life expectancy, but should instead contrast the share of infant mortality with the share of mortality among the aged, then it becomes immediately clear that in Brazil there is not only still a high rate of infant mortality but that mortality among the aged also plays a major role. Indeed that it is already higher. In 1981 deaths under one year of age accounted for $22.1 \%$ of all mortality while those over sixty-five years of age accounted for $34.4 \%$ ! Every tenth burial was, according to official statistics, of a person over eighty years of age $(11.2 \%)$.

It is not my purpose here to enter into a long debate concerning the quality of the sources, for example how high the underregistration of infant mortality, which is doubtless a factor, might be. The mortality pattern among adults is more important for my argu- 
mentation. And this is what is expressed in Table 1, with the complete exclusion of the mortality of infants and small children. Mortality among adults, and not among infants and small children, primarily determines how certain life appears to people who are consciously engaged in making life plans and setting concrete goals for themselves which an historian can later attempt to determine. Figure 2, along with Table 1, does not let any doubt arise that adult life has also become relatively certain in Brazil. More than half of all males $(50.2 \%)$ lived to be 65 years old as early as 1975, for women this figure was almost two-thirds $(64.7 \%)$ (Fundação IBGE ${ }^{10}$, 1986: 125). In the Federal Republic of Germany, by comparison, the figures for $1970 / 72$ were $68.5 \%$ for men and $81.4 \%$ for women (Statistisches Bundesamt ${ }^{40}, 1986: 76$ ). We have to return to the period between the two World Wars in Germany in order to find conditions similar to those which exist in Brazil today: for men back to $1924 / 26(52.7 \%)$ and for women back to $1932 / 34(63.7 \%)$ (Statistisches Bundesamt $\left.{ }^{40}, 1986: 76\right)$.

In the meantime our lives have become biologically so certain in Central Europe that, in $1982 / 84$, more than half of all women $(52.8 \%)$ saw their eightieth and almost half of all men $(47.3 \%)$ saw at least their seventy-fifth birthdays. We are fully aware of this high degree of security which would have been unthinkable a few generations ago. The relatively few who die earlier, primarily because of accidents and suicide, do not impair our feeling of greater biological certainty. Many already believe that they have a right to a life of seventy-five or eighty years. If someome dies earlier then the obituary accusingly asks: "Why so early?"

What is, however, also expressed in Figure 2 is the fact that there are major regional differences within Brazil. This can be seen again in Figure 3. In order to demonstrate the relationship and interdependence of population structure, mortality distribution and causes of death to my post-graduate students, the appropriate data for every Brazilian state were collected in a common effort, analyzed and presented graphically. Figure 3 contains a summary of this work on a superordinate level for the five major regions in Brazil. In the center of the figure the analog segmental representations of the respective parts of Brazil and the Federal Republic are shown.

I hardly need to explain the details in a Brazilian journal of public health. For easily recognized reasons a population pyramid with a wide base rapidly becoming narrower towards the top correlates with a mortality pattern in which there is a high percentage of infant mortality and a relatively wide distribution of mortality in every other age category (the type found in "Norte" and "Nordeste"). These two presentations, in turn, correspond with a mortality distribution in which a high percentage of infectious and parasitic diseases but also symptoms, signs and ill-defined conditions are found (again "Norte" and "Nordeste").

The narrower the base of the pyramid the more mortality is shifted from the youngest to an ever older group (the type found in "Sul" and "Sudeste"), and the higher the proportion in the category II (neoplasms) and VII (diseases of the circulatory system) (again "Sul" and "Sudeste"). This phenomenon is even more obvious in the Federal Republic of Germany today than is the case for the southernmost states in Brazil. Here one finds a reversal in the former ratios and proportions; $20.4 \%$ of the population in the Federal Republic is over sixty years of age (in Brazil, $5.9 \%$, in Rio Grande do Sul, $7.1 \%$ ); $77.3 \%$ of all deaths occur at an age over sixty-five (Brazil 34.4\%, Rio Grande do Sul, 44.0\%). And $74.3 \%$ of all causes of death are based, in the Federal Republic, on neoplasms and diseases of the circulatory system (Brazil, $34.6 \%$, Rio Grande do Sul, 50.2\%).

From this complex I would like to isolate two points for further consideration. Firstly what we see here is the basic transition from the "old" to the "new" form of dying. The further the epidemiological transition has proceeded in a population, the fewer people die of "avoidable" traditional infectious and parasitic diseases and the greater the proportion that dies of cancer and diseases of the heart and circulatory systems. It is not only the distribution of mortality that undergoes a process of change in this context but also the "quality" of dying. Infectious and parasitic diseases may occur at every age, but most of them kill relatively rapidly. It is a quick and gracious death. Chronic conditions do, of course, let us live longe, but they often lead to a long process of dying. Death lets us wait for him. He tortures us often for weeks, months and years before finally taking pity and releasing us. This is what many of us in the First World fear: suffering without end with continually increasing dependency on our 


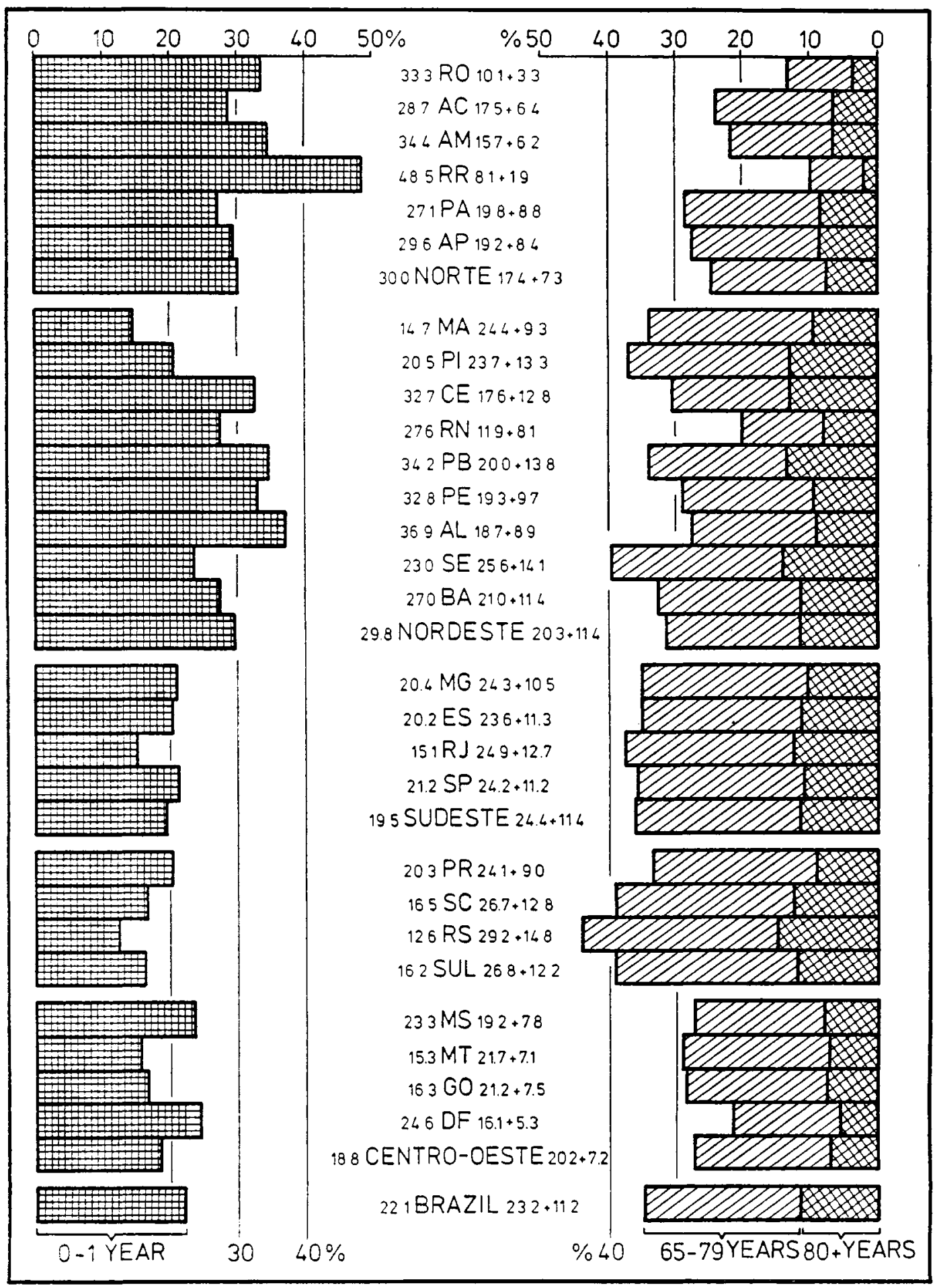

Fig. 2: Infant mortality contrasted with mortality among the elderly in the various Brazilian states in 1981.

Left: Deaths under one year of age as a percentage of total mortality.

Right: Deaths between sixty-five and seventy-nine years of age and eighty years of age and older as a percentage of total mortality.

Sources: Ministério da Saúde²8, 1985; Fundação IBGE ${ }^{10}, 1986$. 


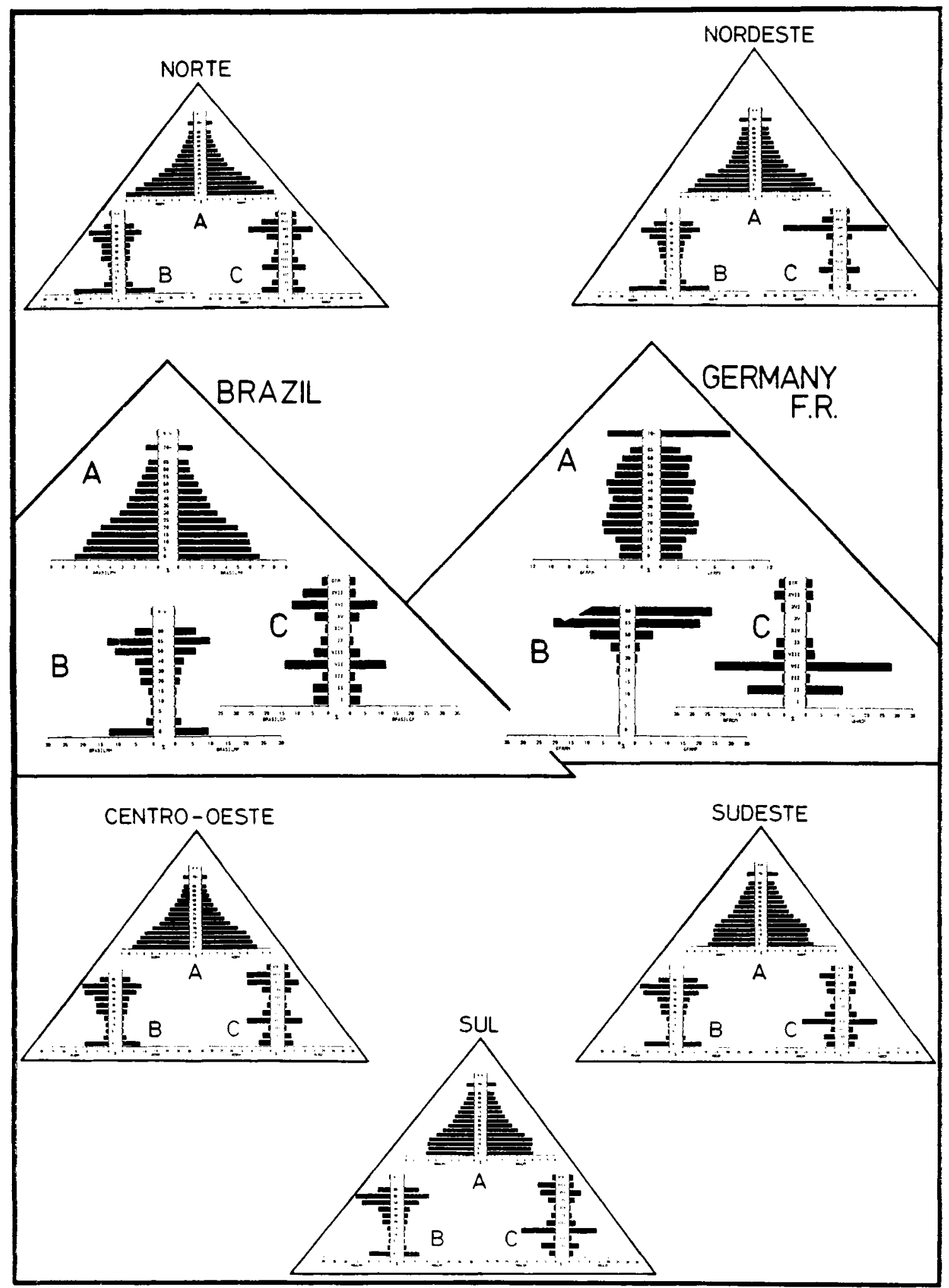

Fig. 3 . See the next page. 
environment, a drawn out physical and psychic struggle with death in a no win situation.

Secondly it is a fact that the Brazilian states in the "Sudeste" region, particularly "Sul", have come the furthest in terms of this development. The segmental representations of the population structure, mortality distribution and causes of death always tend to look the most "European" (for S. Paulo cf. Laurenti e Lolio $\left.^{21}, 1986\right)$. Even if one allows for a large margin of error in these statistics, it is still possible to maintain the principle conclusion to which they lead us. This indicates that the southernmost states have come the furthest on the path from the "old" to the "new" problems: less mortality among infants and small children, therefore more mortality among the aged; less infectious and parasitic disease, therefore more chronic conditions as the cause of death. This was decisive in my making the decision to accept a UFPR and PUCRS guest professorship in southern Brazil. Just as I see myself, coming from Europe where the entire problem reversal has progressed much further, as having a responsibility to point out problems which are likely to be of great importance in Brazil in the near future, I also see southern Brazil as having a special responsibility in relation to the rest of the country. The northern, north-western and central-western regions are likely to follow the southernmost region in this problem reversal a few generations later. To make a generation of young academics at universities in the southern states Rio Grande do Sul and Paraná aware of this development, and to have them reflect upon it today, was the goal and purpose of a postgraduate course on "extended lifetimes" in Curitiba and Porto Alegre.

Fig. 3: Relationship among the age structure, mortality distribution and causes of death in the populations of Brazil and the Federal Republic of Germany 194.

(A) Population according to age groups and sex in the five major regions of Brazil in 1980, on the one hand, and in the Federal Republic of Germany in 1984, on the other.

(B) Deaths according to age groups and sex in the five major regions of Brazil in 1982, on the one hand, and in the Federal Republic of Germany in 1984, in the other.

(C) Deaths according to categories of mortality and sex for the five major Brazilian regions and Brazil as a whole in 1982, on the one hand, and for the Federal Republic of Germany in 1984, on the other.

Sources: Fundação IBGE', 1982. (An exact index of the 21 volumes can be found in IBGE 198611, p. 42); Ministério da Saúde ${ }^{28}$, 1985; Statistisches Bundesamt $40,41,42,1985,1986$, 61-63.

The population size 1980/84 and deaths 1982/1984 for Brazil and Federal Republic of Germany, and for regions and the State of Rio Grande do Sul of Brazil is showed bellow:

Norte/North
Nordeste/North-east
Centro-Oeste/West-Center
Sudeste/South-east
Sul/South
Rio Grande do Sul
Brazil

\begin{tabular}{rrrr} 
& Population & & \multicolumn{1}{c}{ Deaths } \\
1980: & 5.880 .260 & $1982:$ & 28.669 \\
1980: & 34.811 .077 & $1982:$ & 194.817 \\
1980: & 6.367 .860 & $1982:$ & 36.073 \\
1980: & 51.734 .125 & $1982:$ & 368.409 \\
1980: & 19.031 .162 & $1982:$ & 113.646 \\
1980: & 7.773 .837 & $1982:$ & 50.306 \\
1980: & 119.002 .706 & $1982:$ & 741.614 \\
1984: & 61.049 .256 & $1984:$ & 696.118
\end{tabular}

The roman numerals in the (C) segment of the figure are related to the 17 chapters of the "International Classification of Diseases, Injuries and Causes of Death" (ICD), 9th Revision and has been in use since 1979. The usually very low figures for the categories IV-VI and X-XII are not represented individually in Figure 3, but summarized in the top bar. The diseases included in each one of the 17 chapters are the followings.

I Infectious and Parasitic Diseases.

II Neoplasms.

III Endocrine, Nutritional and Metabolic Diseases, and Immunity Disorders.

IV Diseases of the Blood and Blood-forming Organs.

V Mental Disorders.

VI Diseases of the Nervous System and Sense Organs.

VII Diseases of the Circulatory System.

VIII : Diseases of the Respiratory System.

IX - Diseases of the Digestive System.

$X$ Diseases of the Genitourinary System.

XI Complications of Pregnancy, Childbirth, and the Puerperium.

XII : Diseases of the Skin and Subcutaneous Tissue.

XIII : Diseases of the Musculoskeletal System and Connective Tissue.

XIV : Congenital Anomalies.

XV: Certain Conditions Originating in the Perinatal Period.

XVI : Symptoms, Signs and Ill-defined Conditions.

XVII: Injury and Poisoning. 


\section{Long-term Perspectives and Theoretical Framework of a European Historian}

Figure 4 summarizes in a very simplified and schematic form my own research during, roughly, the last twelve years and the theory I have derived from it. In this period I have been able, with a number of research teams, to perform computer analyses of data on the birth, marriage, migration and death of tens of thousands of persons from parish registers from all over Germany. Although isolated parish registers go back to the sixteenth century, uninterrupted soucre material for large areas is only available for the last 300 hundred years. All the segmental figures on the left are related to this earlier period, that is around 1680 , those on the right are for "today", symbolized by the year 1980 .

The individual lines in both graphical segments at the top represent life courses "earlier" and "today". Since only adults, as was mentioned earlier, actively confront the problem of adopting a life plan, a goal in life and with that deciding what form their lives are to take, I have chosen to consider only persons who survived at least until their twenty-fifth birthdays. Three hundred years ago that was about half of every birth cohort in Europe. On the left there is greater discrepancy in the individual life course lines and there are, therefore, a larger number of gaps. On the right, by contrast, only one of these lines is missing. Most people live until their twenty-fifth birthdays today (for men 1982/84 the figure was $97.2 \%$, for women $98.3 \%$; Statistisches Bundesamt ${ }^{40}$, 1986: 76).

Yet even those who "earlier" survived the dangerous infant and early childhood years and lived to become adults were not as sure of the rest of their lives. One died at age thirty-five during a typhus epidemic, a mother of twenty-eight in chidbirth, and another at age fifty of the plague. Others, however, survived all of these dangers and lived to be eighty-five or ninety years old. Life, even adult life, was uncertain. "In the middle of our lives / death is all around us" was a common saying in those days. In the meantime, life has become more certain for the young as well as for the old, certain to an incomparable extent. Three-quarters of all twenty-five year-old men today live to be sixty-five $(75.8 \%)$, for women the figure is as high as nine-tenths $(87.6 \%$; Statistisches Bundesamt ${ }^{40}$, 1986: 76). Only a few die "prematurely".

The two segmental figures in the middle illustrate the cause of this deep-seated change.
Our forefathers prayed the All Souls Litany "Lord preserve us from plague, hunger and war!", which was an appropriate expression of the helplessness in the face of the omnipresent danger of the deadly troika with which they were confronted "Plague" meant all forms of "pestilence", i.e. epidemic infectious diseases (plague, typhus, typhoid fever, smallpox, malaria, and in the nineteenth century cholera asiatica, etc.). "Hunger" was related to the catastrophic effects which recurrent bad harvests had on people and animals. "Wars" did not lead to the death of a great number of people as a result of direct military activity, since armies were relatively small. The greatest number of people died as a result of indirect causes, the tremendous damage caused by war: the frequent marches through a territory, the obligation to quarter soldiers and the comandeering of food. The troops also tended to spread infectious diseases along with them, particularly typhus which was transmitted by the lice likely to be found in dirty uniforms.

The methods our forefathers had for defending themselves against "plague, hunger and war" were quite imperfect and could not provide an entire population with effective protection. Quarantines were often subverted for economic reasons. The few grain reserves that existed were intended for use by the military. Fleeing from "plague, hunger and war" and settling in another location for an adequate period of time was only possible for a very few wealthy individuals. On the whole, it was not particularly difficult for the deadly arrows of the troika to penetrate this imperfect line of defence striking individuals at any place and at any time.

Today, on the other hand, these arrows have become dull or need a much longer time in order to penetrate the much more effective belt of protection which surrounds us, everyone of us. A correspondingly low number of people die "prematurely". On the contrary, ever more people are able tn live out an ever greater part of the life span which nature intended for human beings. The average age of death has risen so far and the individual age at death has become so standardized that most of us today can count on living seventy or eighty years.

Of course we know, particularly the historian knows, that our present situation is fragile. It is true that at the moment we have, and have had for the last three or four decades in Europe, neither notable "pestilences", nor 


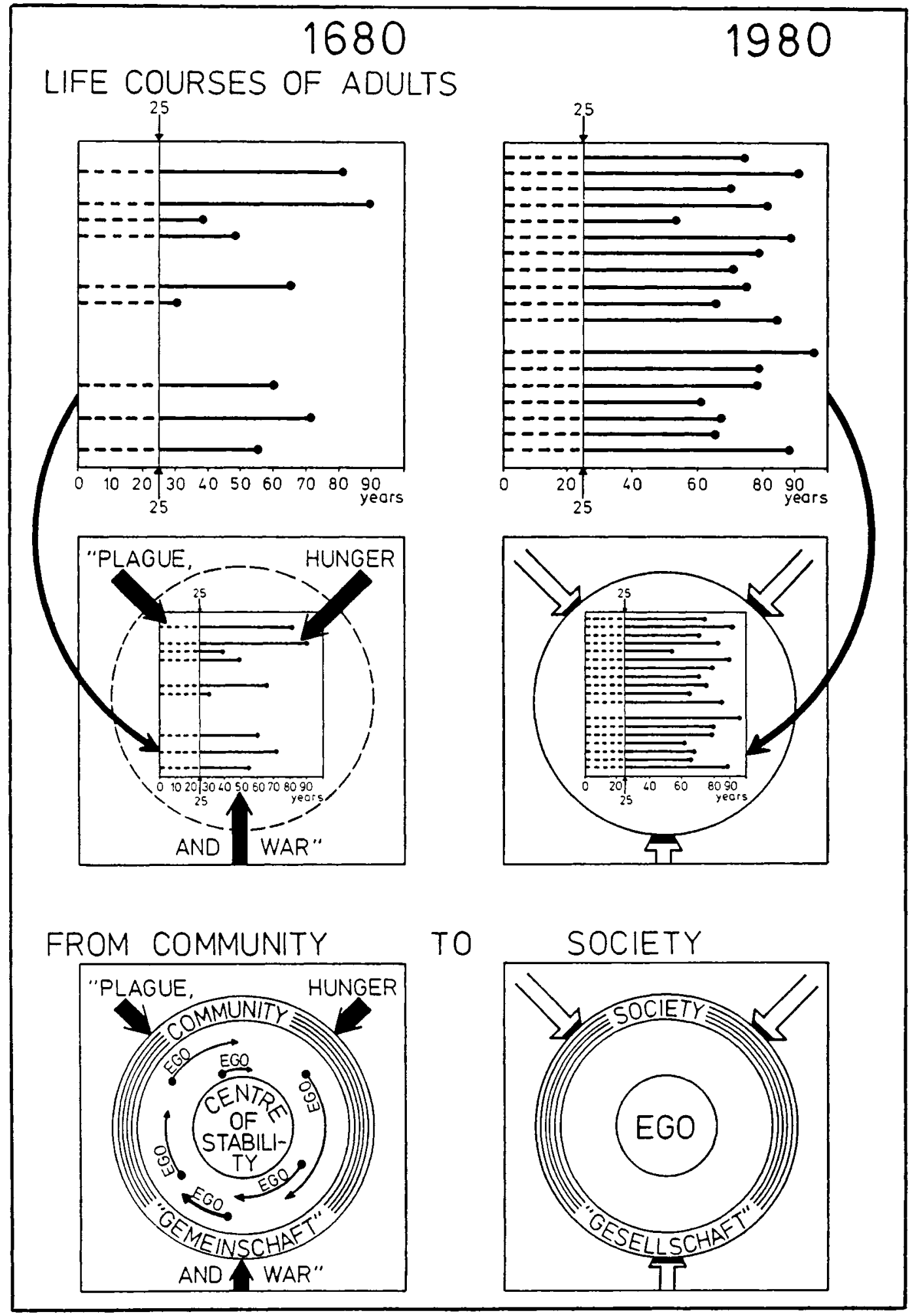

Fig. 4: Life courses of adults and the question of stability in life in Western societies "earlier" (c. 1680; left) and "today" (c. 1980; right).

Source: This topic is dealt with in greater detail in: Planning full-size life careers. Consequences of the increase in the length and certainly of our life spans over the last three hundred years. Ethnologia Europaea 17, 1, 1987. 
hunger nor war. That does not, however, mean that this situation is guaranteed for the future. We have to actively contribute to this ourselves. Yet quite a few Europeans, not the least of which are to be found among the young, are subject in the meantime to a diffuse Angst (anxiety) where our forefathers dealt with a concrete fear of "plague, hunger and war": Angst in relation to new infectious diseases (AIDS!), Angst in relation to poison in our food and the destruction of our environment by pesticides, insecticides, herbicides, forms of energy production which are no longer under control, Angst in relation to an arms race that could end in a catastrophe. Dealing with this diffuse sort of Angst is much more difficult than coming to terms with concrete fear. We by no means live in paradise, even if we no longer have the old problems of "plague, hunger and war". The new ones are not smaller or easier to solve. - How did our forefathers come to terms with their problems? Above all, how did they come to terms with the big problem of the permanent uncertainty of their lives? The lower segmental figures give an answer to these questions.

Since our forefathers were also not able to do without stability in life, and their own lives were just as uncertain as every other, they drew their consequences and did not place any given individual at the center of their thoughts and actions, not even their own EGOs. The center of their world and their Weltanschauung was a value which offered greater stability over a longer period of time. The EGO put itself at the service of this value for the shorter or longer period of time that it was allowed to spend on earth. The center of stability was therefore surrounded by many EGOs with life lines of very different lengths. In actual practice, this center of stability could take on very different forms. In agricultural societies, in which almost all of our forefathers found themselves, the farm played an important role, its unimpaired reputation, its prestige and its welfare. It was the superordinate value which was handed down from generation to generation and in the service of which everyone who lived there placed their lives for as long as they lasted. Everyone belonged to a farm Gemeinschaft, which could not eliminate the uncertainty of individual life spans, but which could mitigate it. Under urban conditions a guild could have been this sort of Gemeinschaft and the center of stability could have been a knowledge of trade secrets. Or one could imagine an artist's circle or the inhabitants of a convent as this sort of
Gemeinschaft, whose members each in their own way orientated their thinking and behavior around a certain central thought, a superordinated, endurable - in accordance with their own ideas immortal - value. Becoming part of such a Gemeinschaft which served a system of superordinate values, to integrate or subordinate oneself within it was necessary at that time for physical survival.

In the meantime these permanent elements of uncertainty "plague, hunger and war" have, for the most part, disappeared from the European scene and the presure to live in closeknit Gemeinschaften has been reduced. We no longer need those "bad old communities", with their tight restraints upon the individual, in order to survive physically. The many years we have on earth are guaranteed to us withuot them. We have therefore liberated ourselves more and more from these cumbersome bonds. They only seemed to restrict our individual freedom in an obsolete manner. To an ever greater extent we place our more certain EGO at the center of our thoughts and actions and seem, to ourselves, to be the center of the world. Our life's goal is self-realization and not the welfare of a superordinate common purpose. The numerous EGOs now live in a relatively impersonal Gesellschaft, in loose ad hoc personal unions with varying participation in this or that interest group, existing alongside each other without having any real relationships to one another (the terms Gemeinschaft and Gesellschaft with exactly these meanings were coined by the German sociologist Ferdnand Tönnies (18551936); (Tönnies ${ }^{44}, 1887 / 1972$ ).

Realizing our full potential is all the easier since most of us are able to afford to make use of the widely available range of goods and services which society offers. The middle class has become very large in Europe. Social services tend to negate the differences between the rich and the poor. Women receive an education equivalent to that of men. In addition to the formerly available roles of only-housewives or mothers they find real alternatives. It seems more and more that human beings are indeed not the "social animals" which they were considered to be up until a short time ago. They only behaved as such for as long as they were forced to by the unfortunate conditions of "plague, hunger and war". As soon as these existential threats began to be diminished they began to show themselves more and more as independent single beings. In Table 2 I have collected some data for the 
TABLE 2

The trend towards living as single beings in the Federal Republic of Germany since the Second World War. Some indicators $1960-1970-1980$.

\begin{tabular}{lrrr}
\hline \multicolumn{1}{c}{ Indicators } & \multicolumn{1}{c}{1960} & 1970 & \multicolumn{1}{c}{1980} \\
\hline Life expectancy men* & 66.9 & 67.4 & 70.8 \\
Life expectancy women* & 72.4 & 73.8 & 77.5 \\
Proportion men over 65* & $\mathbf{8 . 3 \%}$ & $8.2 \%$ & $9.9 \%$ \\
Proportion women over 65* & $11.7 \%$ & $12.4 \%$ & $14.7 \%$ \\
Marriages & 521.445 & 444.510 & 362.408 \\
Divorces & 49.325 & 76.711 & 96.351 \\
Live births & 968.629 & 810.808 & 620.657 \\
Deaths & 642.962 & 734.843 & 714.117 \\
Population increase/decrease & +325.667 & +75.965 & -93.460 \\
Persons per household** & & & 2.43 \\
Federal Republic & 2.88 & & 2.06 \\
Hamburg & & & 1.81 \\
Berlin (West) & & & $31.3 \%$ \\
Single person households** & & & $40.6 \%$ \\
Federal Republic & $20.6 \%$ & & $52.3 \%$ \\
Hamburg & & & \\
Berlin (West) & & & \\
\hline
\end{tabular}

$1960 / 62-1970 / 72-1982 / 84$

$1961-1970-1982$.

Source: Statistisches Bundesamt ${ }^{42}$, 1986, p. 66, p. 70, p. 76, p. 78.

Federal Republic of Germany which impressively document this development during the last two or three decades.

At the very top one sees again how the certainty of our life spans has increased even further and how the proportion of people over sixty-five has also continued to increase. The decrease in the number of marriages and the increase in the number of divorces is just as clear. The divorced wait longer and longer before re-marrying, if indeed they to at all. During the same period of time the number of births sank, whether as a result of the lower number of children per family or as a result of the numerous marriages in which no children were born. The result is that the mean household size has continually become smaller. Particularly the number of one-person households has increased. In 1960 every fifth household was composed of one person $(20.6 \%)$, by 1970 it was every fourth $(25.1 \%)$ and in 1982 every third $(31.3 \%)$. In large cities conditions are even more extreme. In Hamburg $40.6 \%$ of all households were composed of only one person in 1982, in Berlin (West) the corresponding figure was $52.3 \%$. More than half of all households in Berlin (West) are one-person households, whether as a result of divorce or the death of a spouse, or because the inhabitants have either not yet married or will never marry.

Single persons are, in principle, infertile. For years the number of births in the Federal Republic has been insufficient to make up for the number of deaths. The population has been declining. We are faced not with a population explosion but with a population implosion; not the propagation of birth control but just the opposite, the encouragement of more births - in case that is what we really want. Politicians, particularly those responsible for the family, seem to want this. The long-term historical perspective, as I have just shown, might serve to teach us that their ad hoc measures, which usually only amount to financial manipulation, are not far-reaching enough to be able to put a stop to - let alone reverse - a trend towards living as single beings which has been underway for such a long time. All the figures presented seem to indicate that we are less and less willing to enter into long-term ties and responsibilities, whether with a partner or with a child. The increasing number of "group living arrangements" or of "marriages without a license" do not refute these findings. In these cases we are by no means dealing with $G e$ meinschaften of the traditional type described above. They are not a consequence of survival strategies, but rather also serve the purpose of more self-realization, more personal enjoyment, more personal satisfaction.

Hence, the politicians' appeals for "more family", "back to the family" and "more children" will only find resonance among a very few of our contemporaries. It will not be possible to influence the trend towards life as single beings in the long run by means of simple financial motivation or tax disadvantages. Only very few convinced single men 
or women are likely to establish a family and have children only because one-person households might be threatened with higher taxes. It is just as unlikely that very many women will be willing to have more children, or to have children at all, because more numerous day care centers and an additional vacation year are promised. This deep-seated change from an uncertain to a certain life span which has taken place over the course of the last three centuries has freed the individual from the centuries-old pressure to build Gemeinschaften and has set him free in a way that can not be reversed by superficial administrative measures.

\section{The Brazilian Facts Within this Framework}

I have described the deep-seated change from an uncertain to a certain lifetime in such detail and outlined the effects it has on our living together so drastically in order to encourage Brazilians, who seem to be moving in the same direction, to start thinking about it now. In case they want to try and influence this development which is becoming noticeable there as well, it is likely to be easier now than it will be when they have arrived at the same point were Europe finds itself at present.

Far be it from me to claim that the trend to a growing number of single beings is only a result of the increase in life expectancy, that is a life that has become certain for everyone and caused the Gemeinschaften which were formerly necessary for survival to become superfluous. The continual transfer of traditional family functions to superordinate institutions (such as kindergartens, public schools, hospitals, retirement plans, homes for the aged) played, of course, just as important a role as the better education of women to the extent that they more often become fully qualified for professions, or the existence of a large middle class, mentioned above. Nevertheless, the transition from an uncertain to a certain lifetime undoubtedly belongs inseparably and constitutively to this complex and, therefore, to the area of public health as well, in the competence of which it for the most part falls. Table 3 is meant to encourage its readers in reflecting upon this topic.

TABLE 3

Marriages, legal separation, diverse and live births, Brazil, 1982 and 1984.

\begin{tabular}{lrr}
\hline \multicolumn{1}{c}{ Events } & 1982 & 1984 \\
\hline Marriages & 994.246 & 936.070 \\
Total number of legal separations & 41.376 & 63.698 \\
- Number of these by mutual agreement & 35.962 & 54.843 \\
- Number of these without mutual agreement and & & 4.510 \\
simultaneously sought by women: abs.: & 2.713 & $70.3 \%$ \\
Total number of legal divorces in \%: & $67.6 \%$ & 30.847 \\
- Number of these after 7 years of marriage & 27.266 & 1.190 \\
- Number of these after 10-14 years of marriage & 1.183 & 6.976 \\
Live births & 5.757 & 12.920 \\
\hline
\end{tabular}

Source: Fundação IBGE10, 1986, p. 63, p. 64, p. 66, p. 67, p. 68. Departamento Estadual de Estatística 5,1986, p. 51, p. 64.

It would be presumptuous for me, as a foreigner, to claim to competently interpret the statistics. Not only are they related to a much shorter period of time than those for the Federal Republic presented in Table 2, one must also take the fact into consideration that Brazil is just not the Federal Republic. Similar tendencies may very well be the result of different causes. Still, an historian is confronted with a series of factors in Brazil which have played a role for a longer period of time in Europe and which rapidly accelerated the tendency towards single living at an earlier time there. I think, in this context, of increased urbanization, particularly a growing over-metropolitanization, in which Tönnies saw one of the basic elements of the transition from living together in Gemeinschaften toward living alongside each other in Gesellschaften (Tönnies ${ }^{4}, 1887 / 1972$; cf. Table 4). Another important aspect is the growing literacy of the population, particularly the increased ability to read on the part of younger women (Table 5a and $5 \mathrm{~b}$ ). As a result of this new worlds are opened to them causing them to be more independent in many areas of everyday life (EDUCAR ${ }^{7}, 1986$, EDUCAR ${ }^{6}$, 1986, Goody e Watt ${ }^{15}$, 1975, Graff ${ }^{16}, 1981$, $\mathrm{Kramer}^{20}$, 1986). The growing integration of women into the labor market is part of the 
TABLE 4

Proportions of rural, urban and metropolitan population in Brazil 1940/1980. The nine metropolitan areas are: Belém, Fortaleza, Recife, Salvador, Belo Horizonte, Rio de Janeiro, São Paulo, Curitiba and Porto Alegre.

\begin{tabular}{ccccc}
\hline Year & Total population & Rural & Urban & (Metropolitan) \\
\hline 1940 & 41.236 .315 & $68.8 \%$ & $31.2 \%$ & $(11.5 \%)$ \\
1950 & 51.944 .397 & $63.8 \%$ & $36.2 \%$ & $(13.4 \%)$ \\
1960 & 70.070 .457 & $55.3 \%$ & $44.7 \%$ & $(15.8 \%)$ \\
1970 & 93.139 .037 & $44.1 \%$ & $55.9 \%$ & $(17.7 \%)$ \\
1980 & 119.002 .706 & $32.4 \%$ & $67.6 \%$ & $(18.9 \%)$ \\
\hline
\end{tabular}

Sources: Fundação IBGE 10,1986, p. 63, p. 64, p. 66, p. 67, p. 68.

Departamento Estadual de Estatística5, 1986, p. 51, p. 64.

TABLE 5

Adult population in Brazil according to literacy and illiteracy 1900-1980/84. The definition of "literate" is "whoever can read and write a simple text in any language" (Definition in Fundação IBGE", 1986, p. 200).

5 a: Population over fifteen years of age according to literacy and illiteracy, 1900/1980.

\begin{tabular}{|c|c|c|c|c|c|}
\hline \multirow[t]{2}{*}{ Year } & \multirow{2}{*}{$\frac{\text { Literate }}{\text { in } \%}$} & \multirow{2}{*}{$\frac{\text { Illiterate }}{\text { in } \%}$} & \multirow{2}{*}{$\frac{\text { No data }}{\text { in } \%}$} & \multicolumn{2}{|c|}{ Tot a 1} \\
\hline & & & & Absolut & $=100.0 \%$ \\
\hline $\begin{array}{l}1900 \\
1920 \\
1940 \\
1950 \\
1960 \\
1970 \\
1980\end{array}$ & $\begin{array}{l}34.7 \\
35.1 \\
43.8 \\
49.3 \\
60.2 \\
65.9 \\
74.5\end{array}$ & $\begin{array}{l}65.1 \\
64.9 \\
56.0 \\
50.5 \\
39.6 \\
33.6 \\
25.5\end{array}$ & $\begin{array}{l}0.2 \\
0.2 \\
0.2 \\
0.2 \\
0.5 \\
-\end{array}$ & $\begin{array}{r}9.752 .111 \\
17.557 .282 \\
23.709 .769 \\
30.249 .423 \\
40.278 .602 \\
54.008 .604 \\
73.541 .943\end{array}$ & $\begin{array}{l}100.0 \% \\
100.0 \% \\
100.0 \% \\
100.0 \% \\
100.0 \% \\
100.0 \% \\
100.0 \%\end{array}$ \\
\hline
\end{tabular}

5 b: Population over twenty years of age according to age groups, sex, literacy and illiteracy 1984 (total: $67.398 .785)$.

\begin{tabular}{lccccc}
\hline \multirow{2}{*}{ Age } & \multicolumn{2}{c}{ Literate } & \multicolumn{2}{c}{ Mliterate } & \multirow{2}{*}{ Total } \\
& m. & f. & m. & f. & \\
\hline $20-29$ & 87.5 & 88.5 & 12.5 & 11.5 & $100 \%$ \\
$30-39$ & 83.5 & 81.0 & 16.5 & 19.0 & $100 \%$ \\
$40-49$ & 76.3 & 71.0 & 23.7 & 29.0 & $100 \%$ \\
$50-59$ & 71.2 & 61.3 & 28.8 & 38.7 & $100 \%$ \\
$60+$ & 57.6 & 46.5 & 42.4 & 53.5 & $100 \%$ \\
\hline
\end{tabular}

Source: Fundação $\mathrm{IBGE}^{10}$, 1986, p. 60, p. 202.

same complex, even when this happens against their will. With the drying up of the labor market for men and a simultaneous loss in the buying power of the "salário minimo" it seems that many families see themselves with no other choice in the matter of women going out to work (Table 6). Even if they earn only very little, they still earn their own money. For a European historian it is hard to imagine that the increasing rate of general literacy among Brazilian women and their growing integration into the labor market with their own sources of income will not lead to an increasing awareness of their own value as well, and with that to growing self-reliance and independence as was so obvious in Europe in the wake of increased industrialization and literacy in the nineteenth and early twentieth centuries. Perhaps higher rates of divorce and separation documented in Table 3, particularly cases in which there was no mutual agreement and where they were sought by the female partners, are to be seen against this background? Not to mention the reduction in the number of births! To give birth to a child or not is, after all, a woman's decision.

Brazilian readers will undoubtedly be able to interpret the data collected in Tables 4 to 6 more correctly than I am able to as a foreign observer (Mundigo ${ }^{29}, 1986$, Fundação SEADE ${ }^{35}$, 1982). It was only important to me here to point up possible tendencies, possible developments, possible causes and possible con- 
TABLE 6

Female employment - Brazil 1960/1984. All data are adjusted to the value and buying power of the cruzado in mid-1986 (that is after the currency reform and the introduction of the Cruzado Plan (1000 Cr $\$$ (Cruzeiro) $=1 \mathrm{Cz} \$$ (Cruzado). A minimum salary $(=1 \mathrm{SM}=1$ "salário mínimo") is therefore equal to $\mathrm{Cz} \$ 804,60$.

$6 \mathrm{a}:$ The loss of buying power of the minimum salary ("salário mínimo") and the increasing proportion of employed women among all women over ten years of age by constant employment figures among men - Brazil 1960/1984.

\begin{tabular}{cccc}
\hline Year & $\begin{array}{c}\text { Buying power of } \\
1 \text { minimum } \\
\text { salary }\end{array}$ & $\begin{array}{c}\text { Employed men } \\
\text { (among all men over } \\
\text { ten years of age) }\end{array}$ & $\begin{array}{c}\text { Employed women } \\
\text { (among all women over } \\
\text { ten years of age) }\end{array}$ \\
\hline 1960 & $1.580 \mathrm{Cz} \$$ & $77.2 \%$ & $16.5 \%$ \\
1970 & $1.086 \mathrm{Cz} \$$ & $71.9 \%$ & $18.5 \%$ \\
1980 & $973 \mathrm{Cz} \$$ & $72.4 \%$ & $26.6 \%$ \\
1984 & $820 \mathrm{Cz} \$$ & $74.6 \%$ & $35.6 \%$ \\
\hline
\end{tabular}

$6 \mathrm{~b}$ : Growing proportion of employed women, particularly in the "best years" — Brazil 1981/1984. The figures represent the proportion of employed women as a percentage of all women in the given age group.

\begin{tabular}{ccccccccc}
\hline Year & \multicolumn{10}{c}{ A g e } & grou p \\
\cline { 2 - 9 } & $10-14$ & $15-19$ & $20-24$ & $25-29$ & $30-39$ & $40-49$ & $50-60$ & 60 years \\
\hline 1981 & $12.2 \%$ & $38.5 \%$ & $45.8 \%$ & $42.9 \%$ & $42.4 \%$ & $38.4 \%$ & $27.6 \%$ & $9.9 \%$ \\
1984 & $12.0 \%$ & $40.0 \%$ & $49.2 \%$ & $47.0 \%$ & $47.4 \%$ & $42.9 \%$ & $29.8 \%$ & $10.1 \%$ \\
\hline
\end{tabular}

Sources: Fundação IBGE ${ }^{10}$, 1986, p. 132, p. 134, p. 136, p. 148, p. 150-151. Boarini2, 1986.

nections. On the basis of my own experience as a European historian I could not help be noticing them while $I$ was in Brazil. For this reason I have placed them in the spotlight here and would like to vigorously encourage reflection upon them. This is, in any case, what I saw as my job in Porto Alegre and Curitiba. The indicators seem obvious enough to me that one should confront them, and if necessary, react to them. Those active in the field of public health are called upon to a greater extent than others since their work is so closely connected to the questions of life expectancy, epidemiological transition, certainty of physiological life and age at death. Even if one is confronted with far more pragmatic, immediate and concrete problems in everyday practice, one should now and again try to rectify what one is doing in the hight of longterm effects it may have.

\section{ACKNOWLEDGEMENTS}

To the Post-graduate Departments of "Pontifícia Universidade Católica do Rio Grande do Sul" - Porto Alegre (PUCRS) and "Universidade Federal do Paraná" - Curitiba (UFPR) for a second guest professorship in social history and historical demography in 1986; the "Instituto Cultural Brasileiro Alemão" Instituto Goethe - Porto Alegre, and to the German Academic Exchange Service - Bonn (DAAD); and especially to Professors Rene Ernaini Gertz at PUCRS and Sergio Odilon Nadalin and Jayme Antonio Cardoso at UFPR, who made the visit possible, and last but not least to the highly motivated groups of postgraduates for very stimulating team-work. 
IMHOF, A. E. Possíveis consequiências da crescente longevidade no Brasil. Perspectiva de um demógrafo. Rev. Saúde públ., S. Paulo, 21:447-65, 1987.

RESUMO: Em 1985, as pessoas com mais de 60 anos de idade representavam $6,6 \%$ da população total do Brasil, enquanto na República Federativa da Alemanha esta proporção era, em 1984, de 20,3\%; em 1950 havia chegado aos 14,5\%. Esta proporção não será alcançada no Brasil, nem mesmo no ano 2000 , pois se prevê que as pessoas acima de 60 anos comporão $8,8 \%$ da população total. $\mathrm{Da}$ mesma forma, no período 1982/84 a expectativa de vida ao nascer na República Federativa da Alemanha era de 70,8 anos, para homens, e de 77,5 , para mulheres. No Brasil, para $1980 / 85$, foi de 61,0 e 66,0 , respectivamente. Com este pano de fundo entende-se porque 0 debate sobre 0 envelhecimento da sociedade com os seus múltiplos problemas - médicos, econômicos, individuais e sociais - tem demorado a assumir qualquer destaque no Brasil. Embora sejam importantes no Brasil estas consideraçöes, elas constituem, no entanto, presentemente, apenas um lado da história. Para um europeu estudioso de demografia histórica com a vantagem de uma visão de 300 ou 400 anos, o outro lado da história é igualmente importante. $O$ fato de a longevidade estar 10 anos mais baixa no Brasil não significa que ninguém nesse país viva até a idade avançada. Em 1981, pessoas de 65 anos ou mais representaram $34,4 \%$ do total de óbitos; ao mesmo tempo a mortalidade infantil representou $22,1 \%$ da mortalidade geral. Estas e as mortes "prematuras" entre jovens e adultos são responsáveis pela baixa cifra da vida média. Na Europa, por outro lado, as mortes "prematuras" já não desempenham importante papel. Mais da metade das mulheres $(52,8 \%)$ da Alemanha sobreviveram até 80 anos de idade, de 1982/84, e quase metade dos homens $(47,3 \%)$ sobreviveram até 75 anos. A durabilidade da vida é hoje garantida de tal forma que teria sido inconcebível há poucas gerações. O tripé clássico de "peste, fome e guerra" ameaçava os nossos antepassados em todos os lugares e todo tempo. A transição radical de uma vida anteriormente incerta para a vida segura atual, resultado da repressão daquele tripé, levou a consequiências imprevistas para o convívio em comunidade. Nossos antepassados eram obrigados a viver em sociedade, bem integrados na busca de sua sobrevivência física, e subordinar seus dejetos pessoais aos valores comuns; mas, agora, ao menos na sua maior parte, estas pressões desapareceram. $O$ ego, com muito mais segurança, passou a ocupar lugar de destaque. Um número crescente de pessoas tem optado por uma vida solitária: o número de casamentos diminui a cada ano, o número de divórcios aumenta; em Berlim Ocidental, mais da metade $(52,3 \%)$ das "famílias" já se compõe de uma só pessoa. Durante os últimos 6 anos o número anual de nascimentos foi insuficiente para assegurar a reposição da população. O problema da Alemanha não é de explosão demográfica e, sim, de implosão. Os seres humanos já não parecem ser "animais sociais", como se supunha. Na verdade, a "peste, fome e guerra" os obrigavam a este comportamento. Quando estas condições ameaçadoras se modificaram e a vida se tornou mais segura, mesmo sem estarem integrados numa sociedade, os seres humanos vêm se tornando cada vez mais solitários. Não é a existência de população acima de 60 ou 65 anos que se constituiu um fator decisivo neste contexto, mas, sim, a percepção dos adultos de sua condição humana, desde que são eles que organizam suas vidas, que constroem comunidades e que com frequiência cada vez maior contraem uniōes pessoais como um fim em si mesmo, sem laços chegados ou duradouros ou responsabilidades mútuas. Unióes estas que fazem com que as pessoas convivam sem um verdadeiro relacionamento mútuo. Há vários sinais que parecem indicar tendência nesta direção, também no Brasil. Mais e mais adultos estão envolvidos nesta profunda transição de uma vida incerta para outra mais segura. Um terço deles morre depois de ter alcançado seu $650^{\circ}$ aniversário. Já é tempo, pois, de levar em consideração este outro lado da história no Brasil. E quem melhor para estudar estas perspectivas, a longo prazo, do que aqueles da área da Saúde Pública, a quem compete, afinal, lidar com aspectos tais como "certeza de vida", expectativa de vida e "idade ao morrer".

UNITERMOS: Transição demográfica. Expectativa de vida. Envelhecimento da população, Brasil/Alemanha. 


\section{REFERENCES}

1. APRENDER a envelhecer, uma tarefa atual. Gazeta do Povo. Curitiba, 28 set. 1986.

2. BOARINI, M. Viver com pouco salário e muita criatividade. Folha de S. Paulo, S. Paulo, 28 set. 1986 . Folhetim. p. 4.

3. BOEMER, M. R. A Morte e o morrer. São Paulo, 1986.

4. BORN, T. T. A chamada terceira idade entre os nikkies no Brasil. O nikkei e sua americanidade. São Paulo, Massão Ohno, 1986. p. 229-40. (Temas apresentados na III Convenção Panamericana Nikkei).

5. DEPARTAMENTO ESTADUAL DE ESTATISTICA. Dados básicos de região metropolitana de Curitiba: 1985. Curitiba, Secretaria de Estado do Planejamento. Departamento Estadual de Estatística, 1986.

6 FUNDAÇÃO NACIONAL PARA EDUCAÇÃO DE JOVENS E ADULTOS (EDUCAR). Programa de educação básica. Alfabetização. Livro do Professor. Orientações básicas. Rio de Janeiro, 1986.

7. FUNDAÇÃO NACIONAL PARA EDUCAÇÃO DE JOVENS E ADULTOS (EDUCAR). Comissão de Elaboração de Diretrizes Politico-Pedagógicas. Diretrizes político-pedagógicas; relatório. Brasília, 1986.

8. FORATTINI, O. P. Varíola e erradicação? [Editorial]. Rev. Saúde públ., S. Paulo, 19: $385-6,1985$.

9. FUNDAÇÃO IBGE. Censo demográfico $e$ dados distritais. Rio de Janeiro, 1982. v. 1, t. 3, n. ${ }^{\circ} 1-21$ (IX Recenseamento geral do Brasil, 1980).

10. FUNDAÇÃO IBGE. Anuário Estatístico do Brasil, 1985. Rio de Janeiro, 1986.

11. FUNDAÇÃo IBGE. Catálogo do IBGE. 2. a ed. Rio de Janeiro, 1986.

12. FUNDAÇÃO LEGIÃO BRASILEIRA DE ASSISTENCIA. Divisão ao Excepcional e ao Idoso. Programa de Assistência ao Idoso. Temário - Programa de assistência ao idoso. Rio de Janeiro, 1986.

13. FUNDAÇÃO LEGIÃO BRASILEIRA DE ASSISTENCIA. $O$ idoso no Brasil de hoje; Prêmio Eugênio Gudin. Concurso de Monografias. Rio de Janeiro, 1986.

14. GAIARSA, J. A. Como enfrentar a velhice. São Paulo, Icone/Editora da Universidade Estadual de Campinas, 1986.

15. GOODY, J. \& WATT, I. The consequences of literacy 1968. In: Goody, J., ed. Literacy in traditional societies. Cambridge, Cambridge University Press, Paperback-Edition, 1975. p. 27-68.
16. GRAFF, H. J., ed. Literacy and social development in the West; a reader. Cambridge, Cambridge University Press, 1981.

17. HADDAD, E. G. de M. A ideologia da velhice. São Paulo, Cortez, 1986.

18. IDOSOS brasileiros enfrentam filas para conseguir atendimento médico (da reportagem local e das sucursais). Folha de S. Paulo, S. Paulo, 3 out. 1986. p. 16.

19. IMHOF, A. E. Mortality problems in Brazil and in Germany: past-present-future. Learning from each other? Rev. Saúde públ., S. Paulo, 19:233-50, 1985.

20. KRAMER, S., ed. Alfabetização: dilemas da prática. Rio de Janeiro, Dois Pontos, 1986.

21. LAURENTI, R. et al. Estatísticas de saúde. São Paulo, Editora Pedagógica e Universitária/ Editora da USP, 1985.

22. LAURENTI, R. \& LOLIO, C. A. de Mortalidade por doença isquêmica do coração no Município de São Paulo: evolução de 1950 a 1981 e mudanças recentes na tendência. Arq. bras. Cardiol., 46:153-6, 1986.

23. MABILDE, L. C. Velhice normal. Rev. Ass. med. R. G. Sul, 29:130-5, 1985.

24. MACEDO, H. B. de Os meus 90 anos. Curitiba, Editora Litero-Técnica, 1983.

25. MAGALHãES, D. N. Aspectos demográficos, culturais e econômicos do envelhecimento. Bol. Intercâmbio, Rio de Janeiro, 3:5-21, 1982.

26. MÉDICOS vão começar a debater questões relativas à geriatria. Gazeta do Povo, Curitiba, 14 set. 1986 . p. 27.

27. MELLO JORGE, M. H. P. de Sub-registro dos eventos vitais: estratégias para a sua diminuição. Rev. Saúde públ., S. Paulo, 17:148-51, 1983.

28. MINISTERIO DA SAÚDE. Secretaria Nacional de Ações Básicas de Saúde. Divisão $\mathrm{Na}$ cional de Epidemiologia. Estatisticas de mortalidade, Brasil: 1982. Brasília, Centro de Documentação do Ministério da Saúde, 1985.

29. MUNDIGO, A. I. Seminar on the use of demographic knowledge for population policy formulation in Latin America; Lima, Peru, 14-17 January 1986 - An overview. Int. Unioin sci. Study Popul. Newsl,, (27):69-100, 1986.

30. NETTO, A. J. O idoso no ano 2000. [Apresentado no VII Congresso Brasileiro de Geriatria e Gerontologia, Rio de Janeiro, 1985].

31. NETTO, A. J. Política social para a terceira idade. [Aula ministrada no Curso de Gerontologia Social realizado durante o VII Congresso Brasileiro de Geriatria e Gerontologia, Rio de Janeiro, 1985]. 
32. PREFEITURA MUNICIPAL DE CURITIBA. Secretaria Municipal de Desenvolvimento Social. Departamento de Ação Comunitária. Divisão de Alternativas de Trabalho. Programa de fortalecimento dos grupos da terceira idade. Curitiba, 1986.

33. QUEIROZ, P. Z. V. Minorias masculinas: o homem idoso. In: Grandino, A. et al. Macho masculino homem. Porto Alegre, I\&PM Editores, 1986. p. 84-8.

34. QUEIROZ, P. Z. V. Preparação à aposentadoria: uma necessidade emergente neste final de século. São Paulo, Serviço Social do Comérito (SESC), 1986. (Typescript).*

35. REVISTA DOCPOP: Resumos sobre População no Brasil. (Fundação SEADE). São Paulo, v. $1,1982$.

36. SALGADO, M. A. O significado da velhice no Brasil: uma imagem da realidade latino-americana. Cad. Terceira Idade, S. Paulo, 10:7-13, 1982.

37. SALGADO, M. A. Velhice, uma nova questão social. $2 .^{a}$ ed. São Paulo, Serviço Social do Comércio. Centro de Estudos da Terceira idade (SESC-CETI), 1982.

38. STATISTISCHES BUNDESAMT. Todesursachen 1984 (Gesundheitswesen Fachserie 12, Reihe 4: Todesursachen 1984). Stuttgart, Kohlhammer, 1985.
39. STATISTISCHES BUNDESAMT. Sterbefälle nach Todesursachen (Einzelnachweis) 1984 - Arbeitsunterlage. Wiesbaden, Statistisches Bundesamt, 1985.

40. STATISTISCHES BUNDESAMT. Statistisches Jahrbuch 1986 für die Bundesrepublik Deutschland. Stuttgart, Kohlhammer, 1986.

41. STATISTISCHES BUNDESAMT. Sterbefälle nach Todesursachen (Einzelnachweis) 1985 - Arbeitsunterlage. Wiesbaden, Statistisches Bundesamt, 1986.

42. STATISTISCHES LANDESAMT BERLIN. Bevölkerung von Berlin (West) Ende 1984 nach Alter und Familienstand, Berlin, 1986. (Grafik Stala Bln II a 86/57).

43. STATISTISCHES LANDESAMT BERLIN. Bevölkerung von Berlin (West) nach Alter und Geschlecht 1985. Berlin, 1986. (Statistische Berichte A I $3-\mathbf{j} / 85$ ).

44. TÖNNIES, F. Gemeinschaft und Gesellschaft. Grundbegriffe der reinen Soziologie. Darmstadt, Wissenschaftliche Buchgesellschaft, C $1887,1972$.

* The reference indicated with an asterisk will be supply by author.

Received for publication: 23/12/1986 Accepted for publication: 13/5/1987 